\title{
A assinatura de Maria Francisca de Freitas (Capitania de Sergipe de El-Rei,1796)
}

Maria Franscis de Freitas's signature (Capitaincy of Sergipe de El-Rei 1796)

\author{
Vera Maria dos Santos ${ }^{1}$
}

\begin{abstract}
RESUMO
Neste artigo, proponho-me, inicialmente, traçar o perfil de Maria Francisca de Freitas e, em seguida, compreender o seu nível de alfabetização, por meio dos indícios encontrados no inventário de 1796. A análise se desenvolve de modo a descortinar o véu que cobriu a face da mulher sergipana no século XVIII.
\end{abstract}

PALAVRAS-CHAVE: Assinatura. Capitania de Sergipe de El-Rei. Século XVIII.

\begin{abstract}
In this article, I first propose to outline the profile of Maria Francisca de Freitas, and then understand her level of literacy, through the clues found in that inventorie of 1796 . The analysis is developed in order to expose the veil that covered the face of the Sergipe woman in the eighteenth century.
\end{abstract}

KEYWORDS: Signature. Captaincy of Sergipe de El-Rei. Eighteenth century.

$$
* * *
$$

\section{Introdução}

No doutorado em Educação trabalhei com 88 inventários judiciais sergipanos do século XVIII. Foi a partir da transcrição e da análise desses documentos que encontrei o inventário de Manuel Caetano do Lago de 1796, o qual chamou atenção por ter a firma ou assinatura de sua mulher. Tal dado é relevante no século XVIII, porque, conforme a pesquisa de Santos (2016), Maria Francisca de Freitas destoou de um conjunto de 28 mulheres inventariantes que não assinaram os nomes nos inventários de seus maridos.

\footnotetext{
${ }_{1}^{1}$ Professora e pesquisadora do Programa de Pós-Graduação em Educação da Universidade Tiradentes e líder do Grupo de Estudos e Pesquisas: Colonização, Cultura e Educação UNIT/CNPQ. Associada à Sociedade Brasileira de História da Educação (SBHE), desenvolve as suas pesquisas na área de educação, sob o patamar da História da Educação, sobre os seguintes temas: disciplinas e impressos escolares, intelectuais, e sobre o Período Colonial, considerando a relação Sergipe/ Brasil e o Império Atlântico Português. Em 2018 iniciou o projeto de pesquisa "A Ordem Civilizatória Portuguesa: Capitania de Sergipe Del Rey XVIII ao XIX”, financiado pelo Edital MCTIC/CNPq N 28/2018. Este artigo, vincula-se ao mencionado projeto, na medida em que discute o século XVIII, na Capitania de Sergipe Del Rey.
} 
As mulheres, em geral, assinaram a rogo, ou seja, recorreram a um terceiro que era, geralmente, um parente próximo, como o filho, o irmão ou o cunhado, para assinar por ela.

Diante do exposto construí as seguintes indagações: auem foi Maria Francisca de Freitas, no contexto da sociedade setecentista da Capitania de Sergipe de El-Rei? Como ela desenhou ou assinou o nome, fato que contrariou a tese do pesquisador Justino Magalhães (2001), que afirmou que, no mundo ocidental, somente no século XIX a mulher exerceu tal prática? O que a sua firma ou assinatura pode nos dizer sobre o seu nível alfabetização ou letramento da mulher, no século XVIII? São questões que serão respondidas, ou não, no decorrer da análise do documento. A partir dessas indagações proponho-me a investigar quem foi Maria Francisca de Freitas de modo a traçar o seu perfil, considerando a sociedade setecentista sergipana, num primeiro momento e, em um segundo momento, compreender o seu nível de alfabetização, por meio dos indícios encontrados no inventário de seu marido.

Para subsidiar a análise recorri a autores como Faria (1998), e Santos (2016) para compreender o sentido da família no século XVIII, Pierre Bourdieu $(1999 ; 2002)$ para entender o papel da mulher numa sociedade que se impõe pelo poder masculino. Recorri, ainda, a Magalhães (2001) que, ao analisar a historiografia da alfabetização no mundo ocidental do Antigo Regime, discutiu a importância da assinatura, num dado contexto, ao tempo em que elaborou uma escala de assinaturas para compreender o nível de alfabetização do indivíduo. A firma ou assinatura é, para este autor, a capacidade que se tem de grafar o próprio nome. Ginzburg (1989) foi importante, pois por intermédio do método Indiciário, me guiou para a garimpagem dos vestígios na documentação, auxiliando na investigação das tramas postas nas entrelinhas do inventário de Manuel Caetano do Lago, de 1796.

Assim, esta reflexão histórica, mormente no campo educativo, em torno da vida de Maria Francisca de Freitas, não serve apenas para descrever o seu passado, mas para nos colocar perante um patrimônio de ideias, de projetos e 
de experiências. Essa mulher viveu sob a atmosfera do patriarcalismo que pautava os princípios da educação da sociedade setecentista sergipana.

2. Maria Francisca de Freitas na sociedade setecentista da capitania de Sergipe de El-Rei

Maria Francisca de Freitas e seu marido, o tenente Manuel Caetano do Lago, foram moradores da povoação de Laranjeiras, termo da cidade de Sergipe de El-Rei. O tenente, falecido em 1796, deixou duas filhas órfãs menores de idade, a saber: Micaela, com dez anos e Maria Benta, com dois. Foi nessa próspera povoação que estes personagens deixaram os indícios, as pistas, os traços mais negligenciáveis para que eu pudesse garimpar e recompor as suas trajetórias de vidas.

Vale enfatizar que só "era dado o nome de órfão aquele que tinha perdido o pai. A morte da mãe não criava orfandade, pois o viúvo era automaticamente o administrador dos bens dos filhos menores, não havendo, portanto necessidade de um tutor" (SILVA, 1998, p. 39). Assim sendo, o homem era, por direito, o administrador legítimo dos bens dos menores, não cabendo, neste caso, o pedido de tutoria. Assim compreendido, o pai não estava obrigado a passar por um processo de comprovação de sua idoneidade moral, como aconteceu com todas as dez mulheres analisadas no estudo de Santos (2017). Neste sentido, é possível inferir o seguinte entendimento:

as mulheres são excluídas de todos os lugares públicos (assembléia, mercado), em que se realizam os jogos comumente considerados os mais sérios da existência humana, que são os jogos da honra. E excluídas, se assim podemos dizer, a priori, em nome do princípio (tácito) da igualdade na honra, que exige que o desafio, que honra quem o faz, só seja válido se dirigido a um homem (em oposição a uma mulher) e a um homem honrado capaz de dar uma resposta que, por representar uma forma de reconhecimento, é igualmente honrosa (BOURDIEU, 1999, p. 62). 
Assim compreendido, a mulher tinha um espaço diferenciado na sociedade colonial, uma vez que as Ordenações Filipinas, que eram o código de normas e condutas à época, tinham a mulher como elemento incapaz, juridicamente. É importante realçar que nessa sociedade viveu-se sob os ares do patriarcalismo e este, por sua vez, conforme Lebrun (2010, p. 35), foi responsável pela "colocação de lado não apenas das mulheres na vida social, mas da especificidade do feminino".

Retomando a análise do inventário, como ficaram duas filhas órfãs menores de 25 anos de idade foi preciso designar um tutor, para cuidar da instrução e dos bens das órfãs, caso não houvesse disposição testamentária a este respeito. $\mathrm{O}$ referido código filipino entendia que a mãe ou a avó podiam ser tutoras dos filhos e netos, desde que elas pedissem uma provisão régia, a qual era emitida pelo Desembargo do Paço. Era esse o procedimento que toda mulher à época tinha de fazer, caso quisesse tomar conta ou gerenciar os bens herdados com a morte do falecido marido e, consequentemente, ser tutora dos filhos órfãos.

Mas sabendo que era daquele modo que a vida funcionava, Maria Francisca de Freitas fez o pedido para ser tutora das suas órfãs, por meio do juiz dos órfãos, ao Desembargo do Paço, que foi encaminhado ao Conselho Ultramarino para julgamento. A viúva passou por uma análise rigorosa na qual era comum analisar os seguintes pré-requisitos, conforme verificou Santos (2016) em sua pesquisa:

1. Se a pretendente a tutora se conservava no estado de viúva e se vivia com honestidade;

2. Se os filhos órfãos menores viviam em sua companhia;

3. Se criava e educava os seus órfãos com amor e zelo de mãe, na forma da lei, obrigando-se a doutriná-los e alimentá-los à sua própria custa, não bastando para isso o rendimento das legítimas;

4. Não dilapidar o patrimônio dos órfãos (SANTOS, 2016, p. 192). 
Após a análise dos quatro pré-requisitos acima citados, julgou-se se a viúva tinha ou não capacidade para assumir a condição tutora e, deste modo, reger e administrar a suas peças e bens das suas filhas órfãos menores de 25 anos de idade. É importante que se frise que esses pré-requisitos constituíam uma obrigação legal, uma vez que a viúva ficava obrigada a educar/instruir, a doutrinar e a alimentar os seus filhos órfãos menores.

Conforme o estudo realizado por Santos (2016), para a mulher exercer de fato a condição de cabeça do casal, como queria Maria Francisca de Freitas, e administrar os seus bens e os das suas filhas órfãs, sempre esbarrava nas restrições jurídicas que limitavam a sua atuação. Por outro lado,

o processo era longo e, às vezes, demorava muito para a viúva conseguir a tutoria dos seus órfãos, como aconteceu com Angelica Maria do Bom Sucesso, que o marido faleceu em 1799, deixando um filho menor de vinte e cinco anos de idade - Antonio José de Barros, com vinte e quatro anos. Passados dezesseis meses, ela ainda não tinha recebido a sua provisão, que se encontrava retida na Bahia, com seu procurador. Mais difícil ainda foi para Ignes Maria de Jesus, que o seu marido faleceu em 1796 e ela só obteve a tutoria dos filhos menores em 1806 (SANTOS, 2016, p. 196).

Não foi muito diferente o caso de Maria Francisca de Freitas, pois o seu marido, Manuel Caetano do Lago, faleceu em 1796 e ela só recebeu a provisão em 1799.

Ainda citando Santos (2016), mesmo Maria Francisca de Freitas sendo uma mulher de posses, buscou, perante a lei, a autorização para administrar os bens deixados pelo seu marido. Não se pode esquecer que, naquela sociedade, a ordem masculina se impunha e, deste modo, ficava difícil para uma mulher que tinha bens, como era o caso da requerente, garantir a sua sobrevivência com dignidade. Almeida comentou o fato: 
as mulheres coloniais estavam mergulhadas em um mundo onde não eram consideradas alternativas dignas outras além de uma casa de clausura ou casamento, e vão viver confinadas em uma constante tensão entre atender às orientações morais, comportamentais e espirituais, ditadas através dos sermões dos párocos, mães, avós e os manuais de cunho moral e espiritual, e as necessidades que se apresentam no viver cotidiano, apontando para a tomada de decisões, no que concerne à sobrevivência (ALMEIDA, 2005, p. 63).

Ainda compondo o perfil de Maria Francisca, é importante fazer uma análise mais detalhada dos bens, recolhidos no inventário do seu falecido marido, Manuel Caetano do Lago, para entender a atividade econômica desta família e a posição social que ocupava na sociedade de São Cristóvão, na capitania de Sergipe de El-Rei. A viúva ficou com os seguintes bens: um engenho de fazer açúcar moente e corrente nas terras de massapê na Comandaroba e todos os seus acessórios, a saber:

Três tachos, um de cobre, dois de ferros, caldeira de cobre, guia de resfriar de cobre, duas aparadeiras, repartideira, pomba, dois carros de carrear, dez cangas e duzentas formas de receber açúcar, caixas de açúcar branco e mascavo, pães de açúcar. Além do engenho, muita terra ficou em seu poder como a que foi comprada do engenho aos religiosos de Nossa Senhora do Carmo, sortes de terras compradas ao Capitão José Pereira de Oliveira, além de mais uma porção de terras que também comprou ao Alferes Joze Ferreira, que vendeu a parte de dois herdeiros, como também todas as canas. Tinha ainda, um sítio de terras na Vila de Itabaiana (SANTOS, 2016, p. 92).

A partir da forma como foram descritos os bens é importante notar que o engenho ficou em atividade e com caixas de açúcar branco e mascavo, prontas para serem comercializadas; certamente, Maria Francisca teve que 
vender essas caixas de açúcar e as canas que ficaram como herança. Havia ainda, na sua extensa relação de bens, outros itens que além de compor o quadro econômico da família, evidenciaram as atividades desenvolvidas no seu cotidiano, tais como:

sendeiros, bois, vacas, garrotes e trinta e um escravos. Outros objetos muitos deles, relacionados à atividade agrícola, como: selas, freios, bride, machados, martelo, foices, torno de ferreiro, enxadas, cavadores, serras, serrote, compasso, ferro chamado diamante e plaina (SANTOS, 2016, p. 97).

A viúva ficou também com terras, animais e 31 escravos. Além desses bens, conforme a pesquisadora acima citada, havia uma roda de ralar mandioca, um produto denunciador de mais um tipo de ocupação desenvolvida por essa família, porque da mandioca emanava o comércio da farinha, constituindo-se em uma atividade econômica importante para a capitania de Sergipe de El-Rei à época. Como se pode perceber, o cotidiano dessa mulher viúva de posses era de muito trabalho árduo, pois coube a ela não só a administração de todos esses bens, mas o seu envolvimento com as atividades mencionadas. Já em relação aos utensílios domésticos, ela possuía cabos de faca de prata, colheres de prata, candeeiros, tachos de cobre, frascos, pratos grandes, estes, exceto os candeeiros, além de serem objetos de valor, representaram o arsenal de apetrechos domésticos que compuseram a casa dessa dona de engenho. Ressalto que tais itens não eram comuns nos lares coloniais sergipanos. Falando em valor, vejamos com quanto Maria Francisca de Freitas ficou em termos monetários. O Quadro 1 explica a situação financeira da viúva:

Quadro 1 - Montante-mor de Maria Francisca de Freitas

\begin{tabular}{|l|l|l|l|l|l|}
\hline Inventariado & Inventariante & Ano & $\begin{array}{l}\text { Montante- } \\
\text { mor }\end{array}$ & $\begin{array}{l}\text { Montante- } \\
\text { líquido }\end{array}$ & $\begin{array}{l}\text { Cidade, } \\
\text { villa ou } \\
\text { povoação }\end{array}$ \\
\hline
\end{tabular}




\begin{tabular}{|l|l|l|l|l|l|}
\hline $\begin{array}{l}\text { Manoel } \\
\text { Caetano do } \\
\text { Lago }\end{array}$ & $\begin{array}{l}\text { Maria } \\
\text { Francisca de } \\
\text { Freitas }\end{array}$ & 1796 & $12: 532 \$ 190$ & $3: 190 \$ 700$ & $\begin{array}{l}\text { Cidade de } \\
\text { Sergipe de } \\
\text { El-Rei }\end{array}$ \\
\hline
\end{tabular}

Fonte: Elaborado pela pesquisadora a partir dos registros encontrados no inventário de Manuel Caetano do Lago, de 1796.

Para entender melhor o quadro, é importante evocar Santos (2016) que analisou a fortuna da família:

A fortuna de Manoel Caetano do Lago chamou a atenção, porque ele tinha um patrimônio avaliado em 12:532\$190 (doze contos, quinhentos e trinta e dois mil e cento e noventa réis). No entanto, deixou uma dívida de mais de $75 \%$ do valor da sua fortuna, que era 9:341\$490 (nove contos, trezentos e quarenta e um mil quatrocentos e noventa réis). Após a quitação das dívidas do falecido, restaram 3:190\$700 (três contos, cento e noventa mil e setecentos réis). Este valor foi dividido entre a tutora, Maria Francisca de Freitas, que ficou com 1:595\$395 (um conto, quinhentos e noventa e cinco mil e trezentos e noventa e cinco réis) e entre as duas herdeiras do casal, que ficaram cada uma com o valor de $797 \$ 695$ (setecentos e noventa e sete mil e seiscentos e noventa e cinco réis) (SANTOS, 2016, p. 101-102).

Ainda no estudo de Santos (2016), ficou evidente que a fortuna das mulheres inventariantes estava diluída em bens de ouro, prata e cobre, além de escravos. E, considerando este fato, é importante notar que, entre esses objetos deixados pelo defunto seu marido, estavam aqueles que denunciavam nobreza, tais como: quantidade de escravos, cavalos de raça e certos tipos de armas, como o espadim ou outra arma equivalente e, ainda, o modo de falar e de vestir-se. Este conjunto de atributos revelava um estilo de vida próprio de quem era nobre. Porém, ressalto que ser nobre na colônia era diferente de ser nobre em Portugal, onde esse título estava atrelado à herança sanguínea, além da fortuna e da incorporação de comportamentos adequados a este grupo. Ser nobre na colônia implicava:

estilo de vida e 'tratar-se à lei da nobreza', como por exemplo ter criados 
(ou escravos), dispor de cavalos (ou seja, não andar a pé), trajar de acordo com a condição social, possuir uma espada ou arma equivalente. A mulher e as filhas de um nobre deviam ter uma vida recolhida, não se mostrando em público senão em ocasiões especiais e sempre em lugares onde não se misturassem com a massa da população. $O$ estilo de vida nobre tinha de ser mantido a todo custo, mesmo que os bens de fortuna não abundassem, pois só assim se evita a desqualificação social (SILVA, 2005, p. 321-322).

Ainda nessa discussão, vale destacar o que o dicionarista da época entendeu por nobreza:

De teu primeiro pay procederão os primeiros homens com igual nobreza, como filhos do primeiro Rey do mundo, mas com variedades de inclinações se differençarão huns dos outros. Da nobreza das acções se originou a ierarrchia dos nobres, os que com virtudes, armas, ou letras se assinálarão, se distinguirão, dos que o ocio, ou avileza do procedimento, ou a baixeza do officio deixou na humilde esfera dos plebeios. Divide-se a nobreza em hereditaria, e política ou civil. A nobreza hereditaria he huma antiga sucessão de sangue de huma família, que teve pessoas ilustres, e famosas em armas, e letras, ou em outro exercicio honesto, dos antepassados se derivou da gloria dos seus descendentes. A nobreza politica, ou civil, he aquella que alguem logra, não pela sucessão do sangue mas por respeito do posto, ou cargo nobre, que exercita. Huma e outra nobreza sem a da virtude que nos acredita nos filhos de Deos, e herdeiros de sua gloria he huma sutil ostentação de fantástica grandeza" (BLUTEAU, 1712 - 1728).

Ainda analisando a relação dos bens dessa "mulher de posses", foi encontrado apenas um banco, compondo o seu mobiliário, mas isso não quer dizer que a sua casa era composta apenas deste item. De acordo com a pesquisa de Santos (2016), ficou evidente que o mobiliário das casas coloniais era escasso, o que pode ser justificado pela falta de artesãos para executar 
tais serviços, além de muito ser caro tal serviço. Por outro lado, convém destacar que outros móveis para compor o ambiente doméstico eram feitos com madeiras não nobre, ou seja, do próprio local em que moravam.

$\mathrm{Na}$ sociedade colonial, costumeiramente, as roupas de cama e de vestir eram, em sua maioria, confeccionadas pelas donas de casa da época, "feitas com panos ordinários e de baixo custo" (FARIA, 1998, p. 233). Também utilizavam a lã dos carneiros e das ovelhas para confeccionar as peças do vestuário. Portanto, não causaria espanto que os indivíduos daquele tempo tivessem só a roupa de vestir no momento da morte, como assinalou Faria (1998). Cabe destacar também que, naquele período, as roupas eram pouco comercializadas. No caso de homens mais ricos, estes deixaram as peças de um vestuário um pouco mais sofisticado, como foi encontrado entre os bens herdados por Maria Francisca de Freitas, o registro de chapéus, um adorno importante para a época. Essa "mulher de posses" herdou, ainda, fivela de prata, botões de ouro, anel de pedras, esporas de prata.

Chamo a atenção para o termo utilizado - mulher nobre. Na verdade, o título de nobreza era atribuído aos homens e não às mulheres. Estas se tornavam nobres por extensão, devido ao fato de serem casadas com homens nobres. Para Bourdieu, "o nobre não é somente aquele que é conhecido, célebre, e mesmo conhecido como bem, prestigioso, em resumo nobilis. Ele é aquele que é reconhecido por uma instância oficial, 'universal', quer dizer, conhecido e reconhecido por todos" (BOURDIEU, 2002, p. 148, grifo do autor). No caso de seu marido, o Manuel Caetano do Lago tinha a patente de coronel, elemento esse que diz muito sobre a posição que essa família ocupou na sociedade colonial, pois não era todo indivíduo que alcançava tal distinção. Para a obtenção de ofícios e patentes era preciso ter grande poder de influência, pois dependia "de algum apadrinhamento de algum indivíduo poderoso no Reino" (FURTADO, 2006, p. 52). "A prática de favorecimento de ofícios e patentes provocava o estabelecimento de cadeias de clientelismo as quais, ao mesmo tempo, aumentavam o poder daqueles que concediam os favores" (FURTADO, 2006, p. 52). 
É dentro desta seara que a família em questão é focalizada: pela posição que ocupou, no microcosmo social constituinte da elite local, que são os grupos "que por sua posição social, figuraram entre os grupos de maior status, poder e renda" (VELLASCO, 2004, p. 213). Neste sentido, os grupos de elites são diversos: “os dirigentes', 'as pessoas influentes', 'os abastados', ou os 'privilegiados', e isto, na maior parte dos casos, sem uma outra forma de justificação, uma vez que o poder da elite impor-se-ia por si próprio e prescindiria de maiores explicações" (HEINZ, 2006, p. 8). "As elites são definidas pela detenção de um certo poder ou então como produto de uma seleção social ou intelectual [...]" (HEINZ, 2006, p. 8). É importante chamar atenção para outro ponto que reforça a discussão do prestígio social que é o tratamento "Dona", colocando antes de seus nomes de forma abreviada (D.), elemento que aparece nos inventários das pessoas importantes. Esse tratamento era destinado às mulheres cujos maridos tinham título nobiliárquico. Realmente Maria Francisca de Freitas foi casada com um homem detentor de cargo e, por consequência desta ocupação, tanto ela quanto suas filhas faziam uso do "Dona" como sinal de distinção e de prestígio social.

Assim, no microcosmo de São Cristóvão, Maria Francisca de Freitas foi uma mulher dotada de muitos bens, mas mesmo ocupando um lugar de distinção na sociedade em que viveu, na resposta que deu à notificação que recebeu do juiz dos órfãos, ela mostrou indignação ante as cobranças do sistema jurídico à época. $\mathrm{O}$ escrivão registrou a sua fala, conforme mostra o documento, com a sua transcrição a seguir:

Figura 2 - Resposta à notificação que Maria Francisca fez para o juiz de órfãos (1796) 


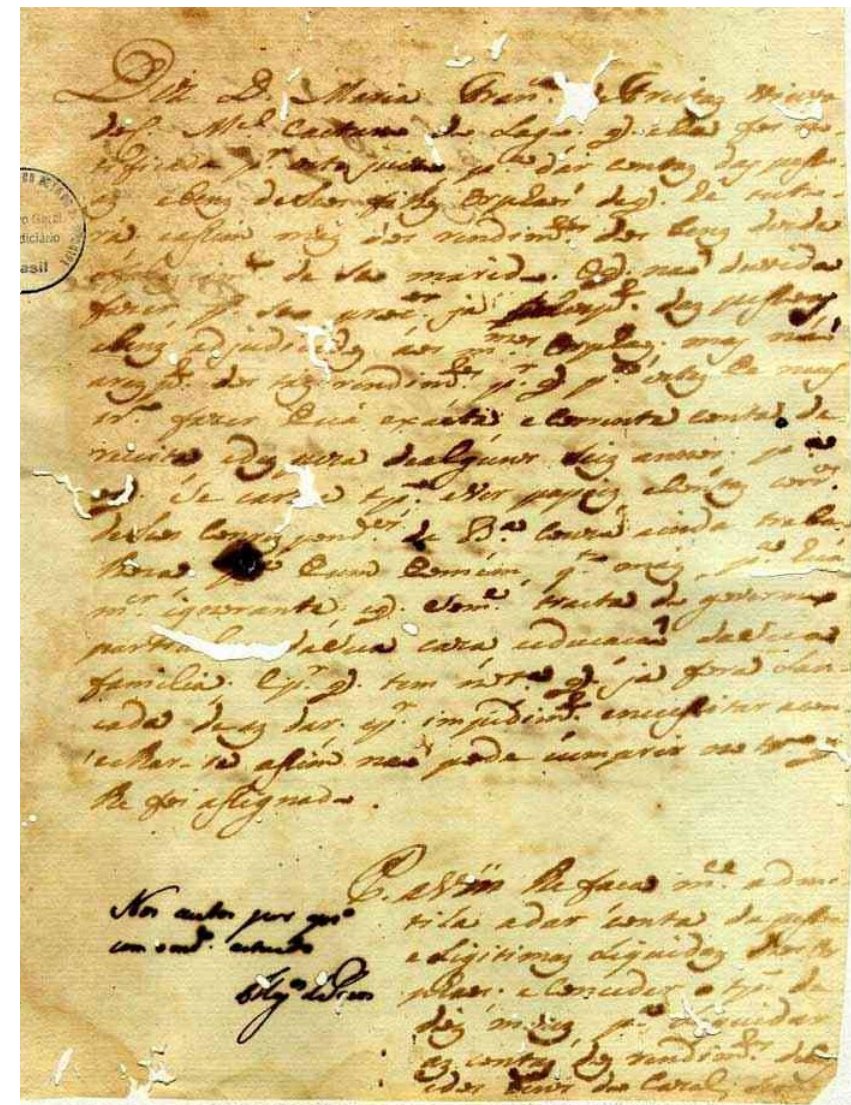

Fonte: Inventário de Manuel Caetano do Lago, 1796, p. 89.

Diz Dona Maria Fran. ${ }^{\text {ca }}$ de Freitas viúva do C. $\mathrm{M}^{\mathrm{el}}$ Caetano do Lago, q. ela foi notificada p..$^{\text {or }}$ este juizo, p. ${ }^{\text {ra }}$ dar contas das pessoas e bens de seus filhos órphãos deq he tutora, [ilegível] mais dos rendimentos dos bens herdado do faleciment ${ }^{o}$ do seu marido. O q. não duvida fazer, para seu [ilegível] já [ilegível] das pessoas e bens adjudicados aos m. mos órfãos mas não a respeit. ${ }^{o}$ dos tais rendimentos, $p^{r}$.q. p. ${ }^{\text {ra }}$ estas he necessário fazer hua exacta, e corrente conta da receitas, e despesa de alguns seis annos, p. ca. [corroído] se [corroído] [ilegível] e ver papeis, e contas corr. ${ }^{\cos }$

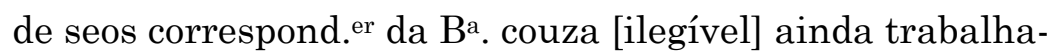
lhara, [ilegível] hum homem, q. ${ }^{\text {to }}$ omais, p. ${ }^{\text {ar }}$ hua 
m. ${ }^{\text {er }}$ ignorante, eq. sem. ${ }^{\text {re }}$ trata do governo parti[corroído] da sua casa, e educação da sua familia, [ilegível] q tem not.çao q já fora lancada de as dar, [ilegível] impediment. ${ }^{\circ}$ e necessitar aconselhar-se assim não pode cumprir no termo que lhe foi assinado.

Pesso refaça m. ${ }^{\text {ce }}$ administar nos autos e dar contas das pessas e legitimas liquidas dos orphaus e conceder o tempo de dois meis p.ra liquidar as contas dos rendimentos dos bens do cazal [ilegível] ${ }^{2}$

$\mathrm{Na}$ verdade, o texto reflete um desabafo ou uma reclamação, diante das cobranças feitas pelo juiz de órfãos, sobre a prestação de contas de tutoria das suas filhas órfãs, que Maria Francisca teve que responder, sob pena de perder a condição tutora. Então, ela, num tom de aborrecimento, perguntou, como podia fazer tanta coisa, pois além de trabalhar como um homem e ainda por ser uma mulher ignorante e sempre tratar do governo particular da sua casa, educação da sua família, ainda assim precisava juntar papéis de "alguns seis anos para cá", para resolver a questão das suas órfãs.

Maria Francisca de Freitas governou a sua casa e, convém lembrar, que a casa naquela época era onde se produzia tudo, desde as roupas, comidas, doces, móveis com madeira do próprio lugar, e também era o local onde se tratava dos negócios. Assim, Maria Francisca emitiu esse juízo no qual se evidenciou como era a condição de uma mulher de posses, que até então pareceu não ter uma face, e a partir deste registro, que ficou no inventário do seu marido, se expôs, claro que inserida na tradição patriarcalista e, deste modo, afirmou que trabalhou como um homem para dar continuidade ao patrimônio herdado pelo seu falecido marido.

\footnotetext{
2 Transcrição realizada por Santos (2011), a partir do inventário de Manuel Caetano do Lago de 1796, p. 89.
} 
Maria Francisca cuidou, ainda, da primeira educação das suas órfãs, aquela que começa nos joelhos da mãe, a qual ensina a andar, a falar, a comer, a vestir e a se comportar e depois as encaminhou para a "instrução, própria do seu sexo" que, segundo Santos (2016),

foi o quarto modelo, detectado também através da transcrição e da análise das prestações de contas de tutoria, anexadas aos inventários judiciais. Essa instrução foi destinada às órfãs menores de posse da Capitania de Sergipe De El-Rei, nos anos setecentos, não contemplou o aprendizado da leitura e da escrita, tendo em vista o papel social desempenhado pela mulher daquele tempo. (SANTOS, 2016, p. 295).

Ainda citando Santos (2016, p. 296), “a instrução própria do seu sexo” apresentava duas dimensões: a primeira era a formação ética e religiosa, evidenciada nos ensinamentos da doutrina cristã e dos bons costumes, que deviam ser inculcados na criança desde a tenra idade; a segunda dimensão era a prática ou a aprendizagem de ofícios. Essas práticas educativas podiam ocorrer tanto no ambiente doméstico, quanto a partir da contratação de um pároco, de um padre para o ensino da doutrina cristã e dos bons costumes, como também da contratação de mestras para o ensino de cozer, fiar e fazer renda. Mas é importante notar nessa discussão, pelo que vimos até o presente momento, que as filhas órfãs de Maria Francisca não aprenderam a ler nem a escrever, pois a instrução própria do seu sexo não contemplava tais ensinamentos para as mulheres à época.

\section{Indícios do nível de alfabetização de Maria Francisca de Freitas}

Maria Francisca de Freitas foi uma mulher que se diferenciou do conjunto de mulheres sergipanas por saber firmar o seu nome. A maior parte das mulheres assinava a rogo, ou seja, recorria a um terceiro. Conforme verificou Santos (2016), esta constatação remete ao estudo de Magalhães (1991) que, ao analisar a historiografia da alfabetização no mundo ocidental 
do Antigo Regime, afirmou ser muito comum, até o século XIX, a mulher assinar a rogo:

Não se encontrou ainda nenhuma situação, para o período em estudo genericamente os séculos XVIII e XIX, em que a mulher firme de cruz ou por qualquer outro sinal. Em contrapartida, quando, homem e uma mulher não sabem assinar, ele firma de cruz e ela por não saber assinar (roga) [...]. Mas não apenas o caso da mulher, também o caso de alguns serviçais. A mulher tomou no entanto parte activa em processos administrativos como madrinha, como testemunha (caso frequente Inquirições de Genere), ou mesmo como outorgante, ré ou que todavia não firma de cruz, como genericamente a mulher rural não assina antes da segunda metade do século XIX (MAGALHÃES, 2001, p. 124).

Ainda me reportando a Magalhães, que definiu uma escala de assinaturas e estabeleceu como o primeiro nível dessa escala a não assinatura para entender o nível de alfabetismo da população, assim entendeu o pesquisador:

uma escala de assinaturas é um constructo instrumental que permite observar, comparar e medir, num continuum gradual e valorativo, diferentes desempenhos autográficos, no âmbito de um marco teórico complexo, combinado de forma crítica e articulada facetas da alfabetização no contexto da cultura escrita (MAGALHÃES, 2001, p. 101).

A não assinatura é identificada, nos documentos, por meio de siglas ou sinais-assinaturas. Assim, "à mulher iletrada, ou mesmo a mulher leitora (semi-alfabetizada), não lhe é reconhecido o recurso à sigla, vendo-se forçada a 'rogar por alguém que por ela assine"'. (MAGALHÃES, 2001, p. 184). O fato de a maioria das tutoras ser não assinante é bastante significativo, além de ser um forte indicativo da condição feminina na sociedade colonial. À mulher 
na sociedade colonial era comum a aprendizagem de boas maneiras e prendas domésticas, conforme destacou Silva (1998), o papel da mulher nessa sociedade era claramente definido:

elas têm uma casa, que governar, marido que fazer feliz e filhos que educar na virtude. E era para bem desempenhar estas funções que as meninas deviam ser retiradas das casas paternas, onde era descuidada a sua formação, para serem educadas no recolhimento. Os vícios da educação doméstica são descritos fundamentalmente em torno do conceito de ociosidade. Tendo serviçais para a servir, logo a menina pensava estar isenta do "trabalho das mãos" e, sem ter nada que fazer, dormia demais: "e deste demasiado sono vem a fazer-se mole, mais delicada, e mais exposta às rebeliões da carne". Ociosa, adquiria também "uma perniciosa sensibilidade para os divertimentos e espetáculos" e uma grande curiosidade pela vida alheia, procurando "saber tudo o que se diz e o que se faz". (SILVA, 1998, p. 235).

Ressalta-se que, no projeto iluminista português, Luis Antonio Verney elaborou uma proposta de educação para as mulheres. No livro Verdadeiro Método de Estudar há uma dedicatória às mulheres no apêndice de sua última carta, a 16. Dividido em cinco tópicos, o livro, inicialmente, discorre sobre a pretensa inferioridade intelectual da mulher e a sua necessidade de estudos. $\mathrm{O}$ fato de as mulheres não terem acesso à leitura e à escrita lhes causava prejuízos, pois elas ficavam sujeitas a enganações. Assim sendo, recorriam aos parentes para assinar a seu rogo. Em relação a este fato, Verney "achou importante incluir no seu estudo a necessidade dessas mulheres adquirirem conhecimentos que antes estavam reservados apenas à esfera dos homens. $\mathrm{O}$ objetivo, porém, continua a ser o da preservação dos bens dentro de uma mesma família" (RIBEIRO, 2000, p. 115).

Verney lutou para que suas obras fossem adotadas na reforma do ensino levada a cabo no reinado de D. José I, pois essa seria a forma mais eficaz de concretizar o seu ideal pedagógico. Mas apenas o De ortographia 
latina foi incluído entre os livros recomendados para tal reforma. Convém frisar que tal proposta não se efetivou na prática e, assim, a instrução das mulheres continuou sem as inovações propostas por Verney. A inferioridade feminina era um elemento que estava incorporado na sociedade portuguesa. Almeida discutiu o tema ao estudar os escritores portugueses setecentistas, que em suas obras, entre outros pontos negativos, destacaram os defeitos das mulheres. Segundo eles, são sempre os mesmos: "inconstância, hipocrisia, frivolidade, vaidade, extravagância, soberba, ostentação, beatice, presunção, traição, tagarelice, beleza" (ALMEIDA, 2005, p. 82).

Era deste modo que a mulher era vista na sociedade portuguesa e em suas colônias, considerando que a sua função perante a sociedade era a de procriar filhos machos, varões que herdariam as posses do pai para a preservação de seus privilégios masculinos. Convém sublinhar que o inventário em análise não nos permite evidenciar como Maria Francisca de Freitas aprendeu a assinar o seu nome, apenas que ela o assinou como mostram as figuras $3,4,5,6$ e 7 do documento.

Figura 3 - Assinatura de Maria Francisca de Freitas

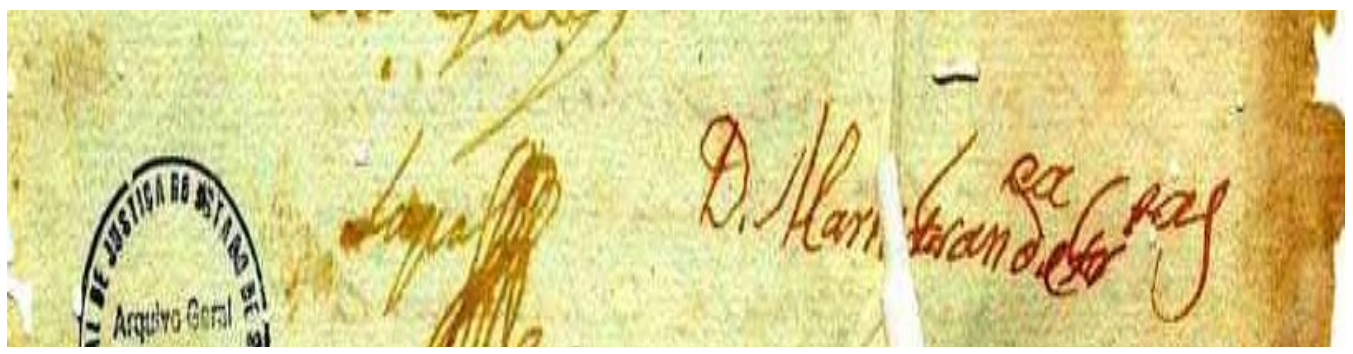

Fonte: Inventário de Manoel Caetano do Lago/1796, p. 02.

Figura 4 - Assinatura de Maria Francisca de Freitas
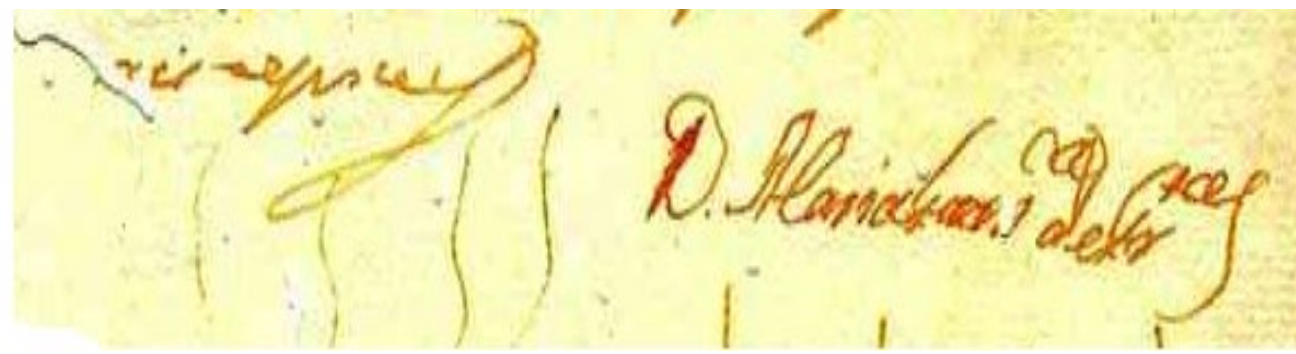

Fonte: Inventário de Manoel Caetano do Lago/1796, p. 20. 
Figura 5 - Assinatura de Maria Francisca de Freitas

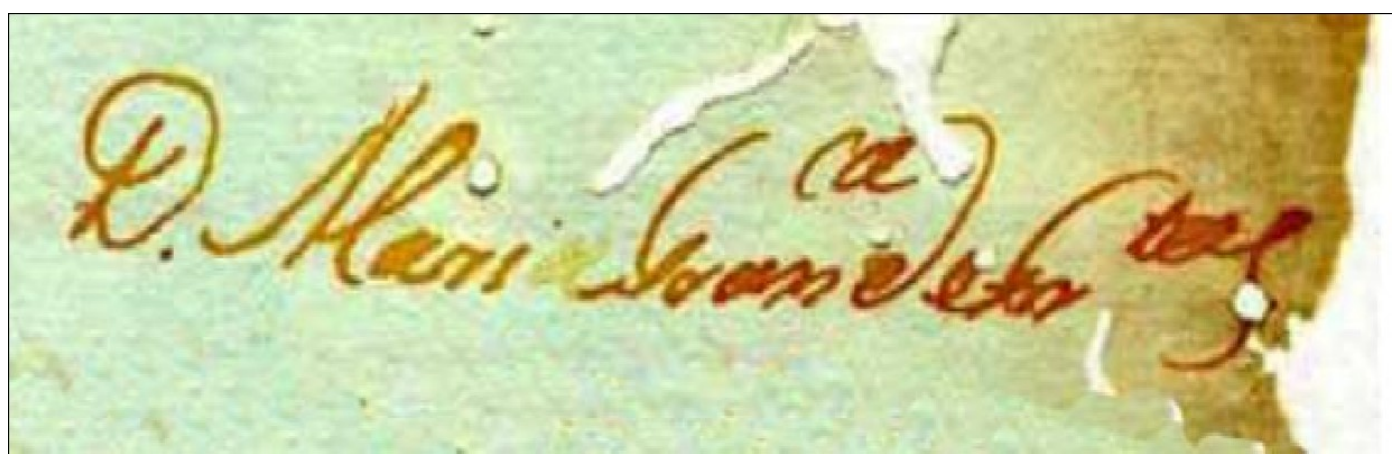

Fonte: Inventário de Manoel Caetano do Lago/1796, p. 22

Figura - 6 Assinatura de Maria Francisca de Freitas

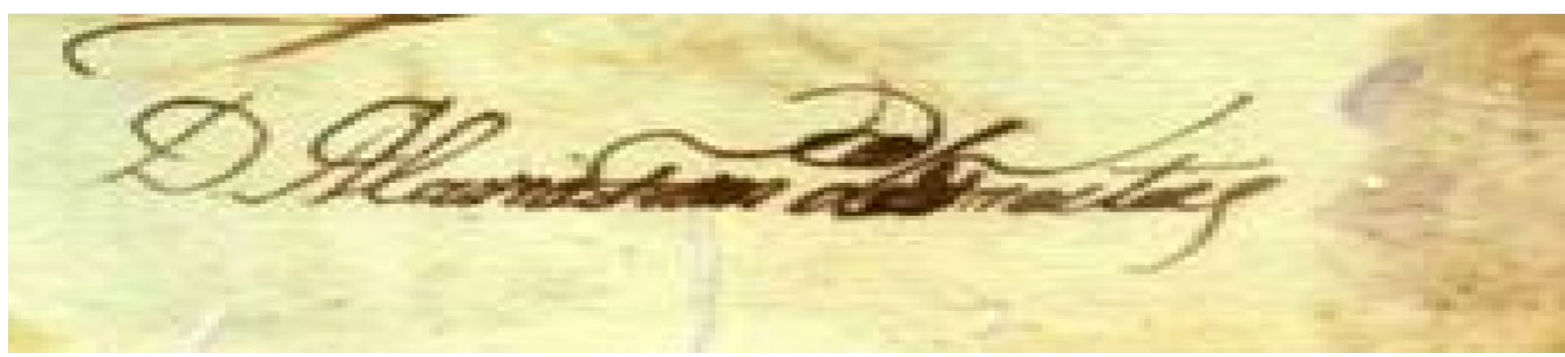

Fonte: Inventário de Manoel Caetano do Lago, 1796, p. 40.

Figura 7 - Assinatura de Maria Francisca de Freitas

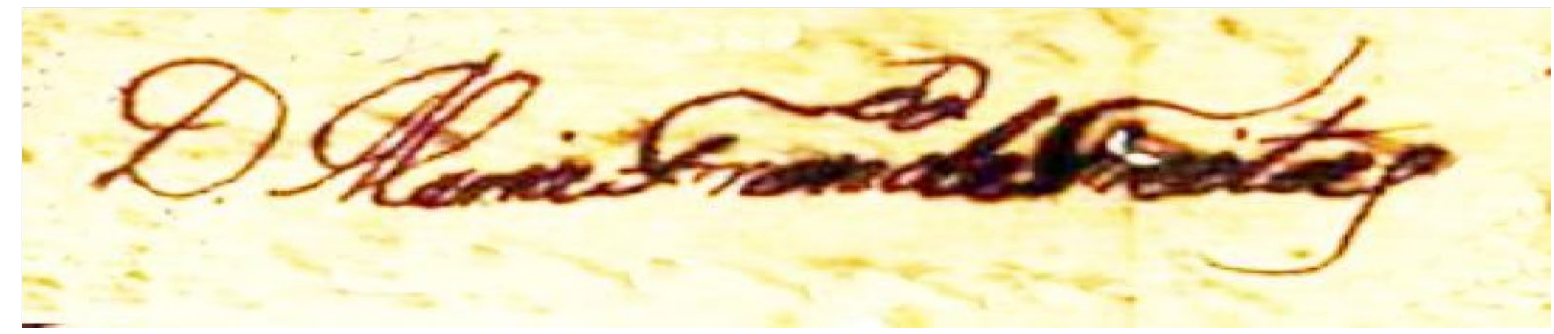

Fonte: Inventário de Manoel Caetano do Lago, 1796, p. 41.

A firma ou assinatura, de acordo com Magalhães, pode ser interpretada no âmbito da História da alfabetização com dois objetivos distintos: "a) a assinatura como factor de distinção entre assinantes e não-assinantes, vulgarmente convertidos em alfabetizados e não-alfabetizados; b) a assinatura utilizada como indicador intrínseco do nível de alfabetismo" (MAGALHÃES, 2001, p. 104). Por intermédio da assinatura de Maria 
Francisca de Freitas é possível vislumbrar no Quadro 2 o nível de alfabetismo dessa tutora, a partir da escala de níveis de leitura e de escrita criada por Magalhães, a saber:

Quadro 2 - Escala de assinatura/práticas de leitura e de escrita

\begin{tabular}{|c|c|c|}
\hline $\begin{array}{c}\text { Nível de } \\
\text { alfabetismo }\end{array}$ & $\begin{array}{c}\text { Escala de } \\
\text { assinaturas } \\
\text { Sinal-assinatura }\end{array}$ & $\begin{array}{c}\text { Escalas de práticas de leitura } \\
\text { e de escrita }\end{array}$ \\
\hline 1. & $\begin{array}{c}\text { Não sabe ler, nem escrever; nada. } \\
\text { incompleta; 'mão } \\
\text { guiada' }\end{array}$ & $\begin{array}{c}\text { Apenas lê e escreve mal; apenas } \\
\text { lê e escreve o nome; apenas lê; } \\
\text { apenas escreve ou faz o nome }\end{array}$ \\
\hline 2. & $\begin{array}{c}\text { Assinatura } \\
\text { completa; } \\
\text { normalizada }\end{array}$ & $\begin{array}{c}\text { Apenas lê e escreve; escreve } \\
\text { sofrivelmente; escreve; lê e } \\
\text { escreve alguma coisa }\end{array}$ \\
\hline 3. & $\begin{array}{c}\text { Assinatura } \\
\text { caligráfica; } \\
\text { estilizada }\end{array}$ & $\begin{array}{c}\text { Lê e escreve; lê e escreve } \\
\text { sofrivelmente; }\end{array}$ \\
\hline 5. & $\begin{array}{c}\text { Assinatura } \\
\text { pessoalizada; } \\
\text { criativa }\end{array}$ & Lê e escreve bem; (formação \\
& acadêmica); \\
\hline
\end{tabular}

Fonte: Elaborado pela autora a partir do estudo realizado por Magalhães, 2001, p. 142.

Os níveis 5 e 4 Magalhães designou de níveis superiores, ou seja, aqueles que têm domínio da leitura e da escrita. Já o nível 3, o autor denominou de intermediário, referente àqueles que possuem uma assinatura completa, normalizada e em relação à escrita e leitura, apenas lê e escreve; escreve sofrivelmente; escreve; lê e escreve alguma coisa. Os níveis 1 e 2 , o citado autor chamou-os de inferiores, sendo que no nível 1 a pessoa não escreve, no entanto se fazia presente por meio de um sinal-assinatura que é definido ou criado pela própria pessoa.

A partir dessa escala de assinatura/ práticas de leitura e de escrita, o citado pesquisador definiu parâmetros de análise e assim entreviu a possibilidade de se estudar o nível de escolarização dos indivíduos, a partir dos testamentos e inventários judiciais. Analisando os níveis dessa escala, entendo que Maria Francisca de Freitas se enquadrou no nível 3, caracterizado por uma assinatura definida como: 
normalizada, completa (podendo ser abreviada). Apresenta um nível de gramaticalização que se traduz num uso criterioso e gramaticalmente correcto das maiúsculas, embora a partícula de ligação possa ainda surgir com maiúscula, num jogo quase perfeito da silabação e num subrelevo das partículas de união das palavras; quando existentes, as abreviaturas tendem para uma estilização que permite a correcta decifração do nome ou dos apelidos (MAGALHÃES, 2001, p. 126).

De acordo a escala de Magalhães (2001), e as minudências postas nas entrelinhas do inventário de seu marido, é possível afirmar que Maria Francisca de Freitas sabia mais do que assinar o nome. Ela sabia escrever e, provavelmente, também sabia ler, visto que redigiu e assinou vários documentos no inventário de seu marido. Foi uma mulher de posses na sociedade sergipana que se distinguiu, também, pela capacidade de firmar o próprio nome. Neste sentido, é importante reconhecer o lugar da diferença de nossa personagem, por saber assinar o seu nome, diante de uma coletividade que à época era não assinante. Deste modo, entendo que Maria Francisca de Freitas, aliada ao poder da sua assinatura, tornou-se uma exceção numa sociedade em que a mulher era excluída do mundo dos homens, por ser juridicamente incapaz de transitar sob uma ordem masculina.

\section{Considerações Finais}

Os inventários judiciais nos permitem fazer uma releitura do período colonial sergipano dentro desta relação Sergipe/Brasil/Portugal, período em que ainda vigoram muitas ideias cristalizadas na historiografia sergipana e brasileira. Um exemplo deste fato é o de que a mulher, no mundo ocidental, conforme Magalhães (2001), só veio assinar o próprio nome no século XIX. Este artigo desconstruiu este entendimento, quando teceu os fios da vida de Maria Francisca de Freitas e mostrou o seu papel na comarca de São 
Cristóvão, capitania de Sergipe de El-Rei. Ela foi uma mulher de posses e com a morte de seu marido herdou um grande cabedal composto de escravos, engenho, caixas de açúcar branco e mascavo, ouro, prata, sítios, terras e dívidas para administrar. Diante de tantas obrigações, emergiu a face de Maria Francisca de Freitas, que exerceu o papel de comando dos negócios e da família, e por isso ressalto que a morte do tenente Manuel Caetano do Lago, seu marido, não representou uma desestruturação na vida econômica dessa família, pois a matriarca, sob a aura do poder patriarcal, conduziu as ações daquele núcleo familiar. E assim, a viúva cuidou ainda da primeira educação das suas órfãs, Maria Benta e Micaela, aquela que começa nos joelhos da mãe, a qual ensina a andar, a falar, a comer, a vestir e a se comportar. Depois, Maria Francisca as encaminhou para a "instrução, própria do seu sexo", a qual envolvia a aprendizagem da doutrina cristã e dos bons costumes num primeiro momento. Em seguida, as órfãs aprenderam a fiar, cozer e a fazer renda, conforme atesta a provisão de tutoria. Ressalta-se que essa era uma obrigação legal e que não devia ser desconsiderada sob pena de perder a condição de tutora.

Com a morte do marido, a viúva de posse assumiu o comando da vida familiar e tornou-se representante do patriarcado, e assim, envolta na aura do poder do pai, Maria Francisca de Freitas administrou o engenho, os sítios com suas plantações, comandou os escravos e negociou os seus produtos que ficaram, a exemplo das caixas de açúcar branco e mascavo. Inserida nesse ambiente de negociações, leu, escreveu e fez contas decorrentes das ações mencionadas.

Advertimos nessa discussão que dentre o conjunto de 37 mulheres analisadas na pesquisa de Santos (2016), ela destoou de maneira significativa do que era comum, que era o fato de a maior parte das mulheres ser não assinante. Neste sentido, é importante reconhecer o lugar da diferença ocupado por Maria Francisca de Freitas por saber firmar o próprio nome, ante uma coletividade que à época não assinava. Assim, aliada ao poder da sua assinatura, tornou -se a exceção ao que era comum, numa sociedade em que 
a mulher era excluída do mundo dos homens, por ser juridicamente incapaz de transitar sob uma ordem masculina. Ela assinou e escreveu documentos no inventário de seu marido e, sob a lupa de Magalhães (2001), entendo que Maria Francisca de Freitas assinou com uma caligrafia enquadrada no nível de domínio da escrita correspondente à assinatura normalizada de nível 3, completa, representada pela assinatura com o uso correto da grafia do nome, podendo ser abreviada ou não. Outro exemplo da sua escrita localizei numa procuração que ela escreveu do seu próprio punho, citada no texto, dando plenos poderes ao seu irmão, Francisco de Paula César, para responder por ela em todas as demandas do inventário, após ser notificada para prestar contas das órfãs e dos bens do casal. A análise da sua assinatura e da procuração nos mostrou que ela estava para além da educação do próprio sexo.

$\mathrm{O}$ fato de ela ser escrevente e assinante reafirma a discussão de que as mulheres, ao final do século XVIII, em Sergipe de El-Rei, demonstraram uma mudança de comportamento, pois começaram a ter acesso aos saberes ler, escrever e contar. No entanto, o acesso a tais conteúdos dependeu muito do ambiente econômico em que elas estavam inseridas, aliado à ocupação que elas desenvolveram à época. Cabe sublinhar que não encontramos assinaturas de mulheres sergipanas nos inventários datados da primeira metade do século XVIII, somente depois da segunda metade do século mencionado, quando a capitania teve os seus índices de desenvolvimento econômico mais elevados, exigiu daquelas pessoas envolvidas com o mundo das negociações de seus produtos agrícolas, o desenvolvimento das habilidades: ler, escrever e contar. Foi nesse ambiente que Maria Francisca de Freitas esteve envolvida e precisou dar continuidade aos negócios da família, mesmo sob a vigilância de um fiador, que podia ser um parente próximo, homem. Contudo, a atitude de mulheres como essa foi importante para tonificar o que mais tarde tornou-se lei obrigatória, a instrução feminina.

Por fim, ressaltamos que pesquisas desta natureza nos mostram que as mulheres assumiram ocupações que, como foi visto, estavam além das atividades domésticas, isso já no século XVIII, na capitania de Sergipe De El- 
Rei. Tais ocupações desmistificam o ideal composto pela historiografia sergipana e brasileira de que a mulher na história viveu submissa, reclusa e sem trabalhar. Afirmamos, ainda, que somente é possível mostrar a verdadeira face da mulher por meio da busca gradativa dos indícios que revelam as práticas cotidianas da vida das mulheres e que permitem fazer uma releitura da atuação feminina em épocas remotas.

\section{Referências}

ALMEIDA, Suely Creusa. $O$ sexo devoto: normatização e resistência feminina no Império Português - XVI - XVIII. Recife: UFPE, 2005.

BOURDIEU, Pierre. A dominação masculina. Trad. Maria Helena Kühner. Rio de Janeiro: Bertrand Brasil, 1999.

BOURDIEU, Pierre. O poder simbólico. Rio de Janeiro: Bertrand Brasil, 2002.

BLUTEAU, Raphael. Vocabulario portuguez \& latino: aulico, anatomico, architectonico. Coimbra: Collegio das Artes da Companhia de Jesu, 1712 - 1728. 8 v. Disponível em: http://www.brasiliana.usp.br/dicionario/edicao/1. Acesso em: 19 mar. 2017.

BRUGGER, Sílvia Maria Jardim. Minas patriarcal: família e sociedade (São João del Rei -séculos XVIII e XIX). São Paulo: Annablume, 2007.

FARIA, Sheila de Castro. A colônia em movimento: fortuna e família no cotidiano colonial. Rio de Janeiro: Nova Fronteira, 1998.

FURTADO, Júnia Ferreira. Homens de negócio: a interiorização da metrópole e do comércio nas Minas setecentistas. São Paulo: Hucitec, 2006.

GINZBURG, Carlo. A micro-história e outros ensaios. Tradução de Antonio Narino. Rio de Janeiro: Bertrand Brasil, 1989.

HEINZ, M. Flávio. (Org.) Por outra história das elites. Rio de Janeiro: FGV, 2006.

LEBRUN, Jean-Pierre. O mal-estar na subjetivação. Porto Alegre: CMC, 2010.

MAGALHÃES, Justino de Pereira de. Alquimias da escrita: Alfabetização, história, desenvolvimento no mundo ocidental do Antigo Regime. Editora da Universidade de São Francisco, 2001.

RIBEIRO, Arilda Inês Miranda. Mulheres educadas na colônia. In: LOPES, Eliane Marta Teixeira; FARIA FILHO, Luciano Mendes de; VEIGA, Cynthia Greive (Org.). 500 anos de Educação no Brasil. História da Educação. Belo Horizonte: Autêntica, 2000. (Coleção História 6) p. 79-94. 
SANTOS, Vera Maria dos. A mulher de posses e a instrução elementar na Capitania de Sergipe De El-Rei nos anos setecentos. 2011, 270f. (Doutorado em Educação) Programa de Pós-Graduação da Universidade Federal de Sergipe, São Cristóvão, 2011.

SANTOS, Vera Maria dos. As mulheres de posses: a instrução dos órfãos menores na capitania de Sergipe De El-Rei no século XVIII. Fortaleza: Imprece, 2016.

SERGIPE. Arquivo Geral do Judiciário. Catálogo dos documentos judiciais do século XVIII de Sergipe: Inventários judiciais da Comarca de São Cristóvão, 2005. Aracaju: TJ: Sercore Artes Gráficas, 2005. Cd rom 1.

SILVA. Eugênia Andrade Vieira da. A elite setecentista instruída em Sergipe Del Rey (1725 - 1800). volume 1. São Cristóvão, 2013.

SILVA, Maria Beatriz Nizza da. História da família no Brasil colonial. Rio de Janeiro: Nova Fronteira, 1998.

VELLASCO, Ivan de Andrade. As seduções da ordem: violência, criminalidade e administração da Justiça: Minas Gerais Século XIX. São Paulo: EUSC, 2004. (Coleção História).

VERNEY, Luís Antonio. Verdadeiro método de Estudar. Lisboa: Presença, 1991.

UNIVERSIDADE DE COIMBRA. Ordenações Filipinas. Livro 1, Titulo LXXXVIII Disponível em: http://www.uc.pt/ihti/proj/filipinas/ordenacoes.htm. Acesso em: 21 abr. 2008.

Recebido em 31 de dezembro de 2020. Aprovado em 18 de janeiro de 2021 